https://doi.org/10.31470/2706-7904-2020-15-255-258

\title{
ТЕНДЕНЦІЇ ВИЯВЛЕННЯ КОМУНІКАТИВНОЇ ТОЛЕРАНТНОСТІ У ПІДЛІТКОВО-ЮНАЦЬКОМУ ВІЦІ
}

\section{Trends in the Expression of Communicative Tolerance in Adolescence}

\author{
Natalya Tokareva \\ DSc. in Psychology, Professor \\ Kryvyi Rih State Pedagogical University (Ukraine) \\ tokareva152681@gmail.com \\ https://orcid.org/0000-0003-1428-3729
}

\begin{abstract}
The article is devoted to the problem of tolerance as a philosophy of humane relations in the modern unstable socio-cultural world. The culture of tolerance is positioned as a culture of the XXI century. The author presents the results of the semantic and interpretive analysis of the concept of «tolerance», defines its psycholinguistic markers. The article reveals the essence of the concept of «tolerance», emphasizes the functional significance of tolerance in the development of personality. Considerable attention is paid by the author to communicative tolerance as the basic mechanism of regulation and humanization of interpersonal communication, and especially in the process of personality maturation. The article presents the results of an empirical study of the tendencies of communicative tolerance of adolescents and young men using the method of V.V. Boyko; the diagnostic resource of this method allows to study the tolerant and intolerant attitudes of the personality. It is proved that the complex development of the communicative tolerance of the personality of adolescents and young men is possible only in the system of professional psychological and pedagogical support of the subject-and sociogenesis in a tolerantly oriented educational space.
\end{abstract}

Key words: tolerance, communicative tolerance, adolescents, mental development, socio-cultural space.

\section{Вступ \\ Introduction}

Полівекторний характер розвитку цивілізації в епоху постмодернізму зумовлює варіативність поєднання вітальних і екзистенційних вимірів життєтворчості людини в несталому просторі буття. У континуумі глобального міжкультурного діалогу найбільш важливим, за нашим переконанням, $є$ прийняття людством системи 
цінностей, в основі якої знаходяться такі психологічні конструкти як гуманізм, взаєморозуміння, терпіння, котрі імпліцитно визначають феноменологію поняття «толерантність», що зумовлює виміри культури XXI століття.

Семантико-інтерпретаційний аналіз поняття «толерантність» (від. лат. Tolerantia - терпляче переносити) дозволяє констатувати різноманітність теоретичних тлумачень базового сегменту континуального поля досліджуваного концепту (Леонтьев, 2009; Растатуева, 2008 та ін.). Етимологічно зміст поняття «толерантність» пояснюється науковцями або у площині англійської мови, де tolerance позначує «готовність і здатність без протесту сприймати особистість або річ», або французької мови, в якій tolerat визначається як «терпимий, поблажливий»; це обумовлює змістові відмінності в інтерпретаційних схемах даного поняття. У семантичному контексті толерантність означує реакцію людини (або групи людей) на зіткнення різних культурних установок, стереотипів, що відбиваються у системі практик; означене зіткнення розв'язується сторонами конструктивно, з акцентом на принципи кооперації і співробітництва (Растатуева, 2008). Толерантність передбачає розуміння відносності суб'єктивних переконань і суджень, неможливість такого їх обгрунтування, що було б беззаперечним для всіх (Лекторский, 1997). Разом 3 тим, толерантність (як визнання рівноправності різних точок зору) пов’язана із відповідальністю особистості за свій вибір і з визнанням за іншими права на власний вибір (збереження їх автономії).

У контексті означеного ми вважаємо за можливе розглядати толерантність як умотивовану психологічну готовність до конструктивного паритетного діалогу 3 людьми, наділеними іншими поглядами, світоглядними позиціями, стилями мислення та поведінки, відкритість до «інакшості» (Лекторский, 1997; Леонтьев, 2009). В якості маркера толерантності розглядаємо здатність визнавати моральні, правові, психологічні кордони (в тому числі - готовність цікавитися іншим як самоцінністю, визнавати його як самодостатню реальність) і вибудовувати конструктивні відносини 3 носіями альтернативних позицій шляхом паритетного діалогу (Токарева, 2015).

Важливою формою реалізації філософії толерантності $є$ комунікативна толерантність - основа та регулятивний механізм спілкування, що сприяє гуманізації міжособистісних взаємин.

Усвідомлюючи значимість толерантності як предиктора особистісного розвитку людини у вимірах сучасного інформаційного суспільства, мету даної наукової розвідки ми вбачали у визначенні тенденцій виявлення комунікативної толерантності протягом підлітково-юнацького періоду особистісного становлення. 


\section{Методи та методики дослідження}

Methods and Techniques of the Research

У якості психодіагностичного інструментарію нами була використана методика оцінювання загальної комунікативної толерантності особистості (В.В. Бойко), діагностичний ресурс якої дозволяє досліджувати толерантні та інтолерантні установки особистості, котрі проявляються у процесі спілкування. Вибірку дослідження склали 235 осіб підлітково-юнацького віку: 115 школярів підліткового віку 13-15 років (учні загальноосвітніх шкіл м. Кривого Рогу (Україна) та 120 студентів (віком 18-22 років) Криворізького державного педагогічного університету.

\section{Результати \\ Results}

Підкреслюючи функціональну значимість толерантності у генезі буття особистості, Д.О. Леонтьев наголошує: «...ухиляючись від діалогу, від взаємодії, ми блокуємо можливості власного розвитку. Тому толерантність ... є важливим ресурсом особистісного розвитку» (Леонтьев 2009: 9). Тож є підстави розглядати комунікативну толерантність як фактор мовленнєво-мисленнєвого та особистісного розвитку суб'єктів життєтворення, і зокрема - протягом дорослішання.

Ранжування значущості для респондентів маркерів комунікативної толерантності (розглядалися перші три позиції середніх значень (Мх)) показало, що в зоні ризику для респондентів знаходяться параметри «Невміння пристосовуватися до характеру, звичок і бажань інших» і «Неприйняття або нерозуміння індивідуальності іншої людини». Респонденти підліткового віку проявляють більш високий рівень інтолерантності за шкалами «Невміння прощати іншим помилки, незручність» $(\mathrm{Mx}=3,4$; I ранговая позиція) i «Нетерпимість до фізичного або психічного дискомфорту, створюваному іншими людьми» $(\mathrm{Mx}=3,2)$, тоді як для студентів значущим маркером інтолерантності стала шкала «Прагнення перевиховати партнера, зробити його «зручним»» $(\mathrm{Mx}=2,8)$. Подальший статистичний аналіз отриманих даних із застосуванням t-критерію Стьюдента для порівняння незалежних вибірок показав відносний характер відмінностей в прояві патернів толерантності респондентами вибіркової сукупності, що свідчить про тотожність особистісних профілів респондентів підліткової та юнацької когорт. 


\section{Висновки \\ Conclusions}

Результати емпіричного дослідження, таким чином, дозволяють констатувати: в особистісному становленні людини нового покоління важливу роль відіграє толерантність як імпліцитний ресурс розвитку ціннісного ставлення до світу. Комплексний розвиток комунікативної толерантності особистості у підлітковоюнацькому віці можливий у системі професійного психолого-педагогічного супроводу суб’єкто- і соціогенезу в умовах толерантно орієнтованого освітнього простору.

Отримані дані можуть бути покладені в основу подальшої дослідницької роботи із визначення специфіки особистісного розвитку суб'єктів дорослішання в умовах глобального реформування системи освіти.

\section{Література}

References

Лекторский, В.А. (1997). О толерантности, плюрализме и критицизме. Вопросы философии, $11,46-54$.

Леонтьев, Д.А. (2009). К операционализации понятия «толерантность». Вопросы психологии, $5,3-16$.

Растатуева, С. Г. (2008). Репрезентация концепта «толерантность» в русском языке. Автореф. дисс. канд. филол. наук. Елец.

Токарева, Н.Н. (2015). Психологія комунікативного моделювання особистісних конструктів у підлітковому віці. Дис. д-ра психол. наук. Київ. 